\title{
Common Worm Media and Buffers
}

\section{Fanglian He}

[Abstract] Here are recipes of some media and solutions often used in C. elegans research.

\section{Materials and Reagents}

1. Agar, peptone (BD Biosciences)

2. Cholesterol (Sigma-Aldrich)

3. Streptomycin (Sigma-Aldrich)

4. Nystatin (Life Technologies, Gibco ${ }^{\circledR}$ )

5. Bleach (Clorox)

6. Potassium phosphate

7. Clorox bleach

8. $\mathrm{NaCl}$

9. $\mathrm{CaCl}_{2}$

10. $\mathrm{MgSO}_{4}$

11. $\mathrm{EtOH}$

12. $\mathrm{FeSO}_{4} .7 \mathrm{H}_{2} \mathrm{O}$

13. $\mathrm{Na}_{2}$ EDTA

14. $\mathrm{MnCl}_{2} \cdot 4 \mathrm{H}_{2} \mathrm{O}$

15. $\mathrm{ZnSO}_{4} .7 \mathrm{H}_{2} \mathrm{O}$

16. $\mathrm{CuSO}_{4} .5 \mathrm{H}_{2} \mathrm{O}$

17. $\mathrm{KH}_{2} \mathrm{PO}_{4}$

18. $\mathrm{Na}_{2} \mathrm{HPO}_{4}$

\section{Equipment}

1. $60 \times 15 \mathrm{~mm}$ plate

2. Plastic boxes 


\section{$\underline{\text { Recipes }}$}

1. Nematode growth medium (NGM) agar: For the maintenance of worms.

For 1 liter medium

$3 \mathrm{~g} \mathrm{NaCl}$

$17 \mathrm{~g}$ agar

$2.5 \mathrm{~g}$ peptone

$1 \mathrm{ml}$ cholesterol (5 mg ml $\mathrm{in}^{-1}$ 95\% EtOH)

$975 \mathrm{ml} \mathrm{H}_{2} \mathrm{O}$

Autoclave, and then add the following sterile solution (autoclaved)

$1 \mathrm{ml} 1 \mathrm{M} \mathrm{CaCl}_{2}$

$1 \mathrm{ml} 1 \mathrm{M} \mathrm{MgSO}_{4}$

$25 \mathrm{ml} 1 \mathrm{M}$ potassium phosphate ( $\mathrm{pH} \mathrm{6)}$ (to avoid precipitation, mix between addition of $\mathrm{MgSO}_{4}$ and potassium phosphate)

To make $1 \mathrm{M}$ potassium phosphate (pH 6): For 1 liter, dissolve $136.1 \mathrm{~g} \mathrm{KH}_{2} \mathrm{PO}_{4}$ in about

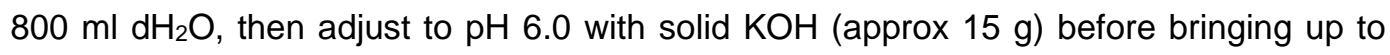
volume. Make $100 \mathrm{ml}$ aliquots and autoclave.

Need to add streptomycin (300 $\mathrm{ng} \mathrm{ml}^{-1}$ ) if plate is used for seeding bacterial food $E$ coli OP50-1. Typically pour $60 \times 15 \mathrm{~mm}$ plate and store NGM plates in plastic boxes with covers at room temperature.

2. S-basal medium (adapted from the Kim Lab at Stanford) : For liquid culture of worms.

For 1 liter medium

$5.8 \mathrm{~g} \mathrm{NaCl}$

$50 \mathrm{ml} 25 \mathrm{ml} 1 \mathrm{M}$ potassium phosphate $(\mathrm{pH} \mathrm{6})$

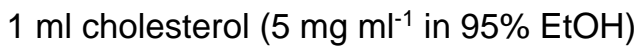

$950 \mathrm{ml} \mathrm{dH_{2 } \mathrm { O }}$

Autoclave, and then add the following sterile solution (autoclaved)

$3 \mathrm{ml} 1 \mathrm{M} \mathrm{CaCl}_{2}$

$3 \mathrm{ml}_{1} \mathrm{M} \mathrm{MgSO}_{4}$

$10 \mathrm{ml}$ trace metals solution

$10 \mathrm{ml} 1 \mathrm{M}$ potassium citrate ( $\mathrm{pH} 6.0)$

$10 \mathrm{ml}$ 100x Nystatin (antifungal agent, keep in freezer; do not have to add it all the time).

To make $500 \mathrm{ml}$ trace metals solution

$0.346 \mathrm{~g} \mathrm{FeSO}_{4} .7 \mathrm{H}_{2} \mathrm{O}$

$0.930 \mathrm{~g} \mathrm{Na}_{2} \mathrm{EDTA}$

$0.098 \mathrm{~g} \mathrm{MnCl}_{2} .4 \mathrm{H}_{2} \mathrm{O}$

$0.144 \mathrm{~g} \mathrm{ZnSO}_{4} .7 \mathrm{H}_{2} \mathrm{O}$ 
$0.012 \mathrm{~g} \mathrm{CuSO}_{4} .5 \mathrm{H}_{2} \mathrm{O}$

Sterilize by autoclaving. Keep in dark (wrap in foil).

To make $100 \mathrm{ml}$ of $1 \mathrm{M}$ potassium citrate: dissolve $21.02 \mathrm{~g}$ citric acid, monohydrate in 80 $\mathrm{ml}$ and adjust to $\mathrm{pH} 6.0$ with solid $\mathrm{KOH}$ (approx $17 \mathrm{~g}$ ) before bringing up to volume.

3. Worm M9 buffer

$3 \mathrm{~g} \mathrm{KH}_{2} \mathrm{PO}_{4}$

$6 \mathrm{~g} \mathrm{Na}_{2} \mathrm{HPO}_{4}$

$5 \mathrm{~g} \mathrm{NaCl}$

Add $\mathrm{H}_{2} \mathrm{O}$ to 1 liter. Sterilize by autoclaving.

After solution cools down, add $1 \mathrm{ml}$ autoclaved/sterile $1 \mathrm{M} \mathrm{MgSO}_{4}$.

4. $100 \mathrm{ml} 2 \mathrm{x}$ worm lysis solution: For worm egg prep

$50 \mathrm{ml} \mathrm{ddH} \mathrm{H}_{2} \mathrm{O}$

$10 \mathrm{ml} 10 \mathrm{M} \mathrm{NaOH}$

$40 \mathrm{ml}$ Clorox bleach

Make fresh and store at $4{ }^{\circ} \mathrm{C}$ up to one week. 